\title{
PENINGKATKAN JUMLAH WIRAUSAHAWAN DI INDONESIA MELALUI KOLABORASI AKADEMISI - PELAKU USAHA - MAHASISWA
}

\author{
Bintang Paula Putra \\ Dosen Program Studi Manajemen, STIE Dewantara \\ J1. Raya Pemda Bojong Depok Baru III, Karadenan, Cibinong, Bogor, Jawa Barat 16913,Indonesia \\ Email: bintang@dewantara.ac.id
}

\begin{abstract}
The latest published information about percentage of Indonesia's entrepreneur from total population was $1.65 \%$ equal to 4.26 million people. This number was still lower than the minimum standard of developed countries, which is $2 \%$. In order to achieve that number the government needs a new strategy which can effectively raise the number of new entrepreneurs which targeted the young generation. The research conducted to analyze seconder data to propose a program called a collaboration among Academics - Small and Medium Enterprises (SMEs) owners - College Students. Lead by selected lecturers, the college students were expected firstly to work together in developing existing SMEs in small groups. The next step was a program to enable them to find opportunities and open their own businesses. The last stage was the evaluations. The mentioned series of activities should be done under the Ministry of Cooperatives and SMEs of Republic of Indonesia and implemented by the departments in local districts cooperated with universities. Research objects were data of total entrepreneurs, universities, and certain data related to Indonesia's economy. The approach of this research was deductive, which aimed to build a new theory formulated to give an idea of how to increase from existing total entrepreneurs to targeted total entrepreneurs. Both qualitative and quantitative techniques were conducted, begun with content analysis, it was followed by basic mathematical calculation. The final result of the research was a proposed program to Indonesia's governement to gain new entrepreneurs from $1.65 \%$ to $2 \%$ as targeted.
\end{abstract}

Keywords: Entrepreneurship, Small and Medium Entreprises, Business.

\begin{abstract}
ABSTRAK
Informasi terpublikasi terakhir mengenai jumlah prosentase pengusaha Indonesia dari total populasi adalah $1.65 \%$ yang setara dengan 4.26 juta penduduk. Angka ini masih dibawah dari standar minimum bagi negara maju, yaitu $2 \%$. Dalam rangka mencapai angka tersebut, maka pemerintah memerlukan strategi baru yang dapat secara efektif menaikkan jumlah pengusaha yang disasar lebih kepada generasi muda. Penelitian ini dilakukan untuk menganalisa data sekunder untuk selanjutnya dijadikan dasar pengajuan ide sebuah program yang merupakan kolaborasi antara akademisi, pemilik usaha kecil menengah (UKM) dan mahasiswa. Diarahkan oleh akademisi-akademisi pilihan, para mahasiswa diharapkan dapat bekerjasama dalam grup untuk mengembangkan UKM yang sudah ada. Langkah selanjutnya adalah serangkaian kegiatan yang memampukan para mahasiswa menemukan peluang bisnis dan membuka usaha mereka sendiri. Tahap terakhir adalah evaluasi. Seluruh kegiatan seyogyanya dilakukan dibawah pengawasan Kementerian Koperasi dan UKM RI dan dieksekusi oleh dinas terkait di daerah-daerah bekerjasama dengan universitas-universitas setempat. Obyek penelitian adalah data tentang jumlah pengusaha, universitas dan informasi lain sehubungan dengan keadaan ekonomi Indonesia. Pendekatan penelitian adalah deduktif, yang bertujuan untuk membangun teori baru yang adalah sebuah ide bagaimana meningkatkan jumlah pengusaha saat ini menuju target nasional. Baik analisa kualitatif dan kuantitatif telah dilakukan. Dimulai dari analisa konten, kemudian dilanjutkan dengan kalkukasi matematika dasar. Hasil akhir dari penelitian berupa pengajuan program kepada pemerintah Indonesia untuk menaikkan prosentase jumlah pengusaha dari $1.65 \%$ menjadi $2 \%$ sesuai target nasional.
\end{abstract}

Kata kunci: Kewirausahaan, Usaha Kecil Menengah, Bisnis. 


\section{PENDAHULUAN}

Negara Indonesia saat ini masih digolongkan sebagai negara berkembang, oleh karena beberapa indikator yang menyatakan ketertinggalan negara Indonesia dibandingkan negara-negara maju. Salah wirausahawan terhadap total penduduk di Indonesia. Mayoritas penduduk terbagi menjadi dua kategori besar, yaitu para karyawan dan wirausahawan. Padatnya penduduk di kotakota besar, seperti Jakarta, Surabaya, Medan, Yogyakarta menyebabkan semakin sempitnya lapangan pekerjaan. Oleh karena itu, penduduk yang tidak memiliki pekerjaan yang tetap dan tidak memiliki kemampuan berwirausaha akan memiliki pendapatan yang rendah dan tidak dapat mencukupi kebutuhan keluarganya. Jika tidak ada upaya menyelesaikan hal ini, maka perkembangan perekonomian di Indonesia tidak akan mengalami peningkatan sehingga Indonesia tidak dapat menjadi negara maju. Oleh karena itu, jiwa kewirausahaan penduduk Indonesia harus ditingkatkan untuk membantu mengembangkan perekonomian Negara Indonesia.

Kewirausahaan sejatinya merupakan salah satu faktor yang dapat merangsang peningkatan perekonomian Indonesia karena memiliki beberapa alasan, diantaranya dapat meningkatkan produktifitas masyarakat, menggairahkan roda perekonomian nasional, mengembangkan kreatifitas dan kemampuan masyarakat, masyarakat tidak bergantung kepada pemerintah, dan juga dapat meningkatkan devisa dan menarik investor negara asing untuk menanamkan modalnya di Indonesia, apabila kewirausahaan berjalan dengan lancar.

Jumlah wirausaha di Indonesia pada saat ini masih menunjukan presentase yang sangat kecil, yaitu belum mencapai $2 \%$. Puspayoga selaku Menteri Koperasi dan Usaha Kecil Menengah RI mengatakan bahwa saat ini Indonesia baru memiliki
$1.65 \%$ pengusaha dari sekitar 258 juta penduduk Tanah Air. Indonesia masih membutuhkan sekitar 900 ribu pengusaha baru untuk mencapai angka $2 \%$. Sedangkan di negara ASEAN seperti Singapura tercatat sebanyak 7\%, Malaysia 5\%, Thailand 4,5\% dan Vietnam 3,3\% jumlah wirausahawannya. Tolak ukur sebuah negara maju ditinjau dari persentase jumlah wirausahanya adalah sebesar minimal $2 \%$ dari total jumlah penduduk. Indonesia masih jauh tertinggal oleh negara-negara tetangga yang memiliki jumlah wirausaha lebih tinggi. Seperti Singapura yang merupakan Negara dengan jumlah wirausaha tertinggi di ASEAN, kemudian Malaysia. Hal ini cukup memprihatinkan, mengingat Indonesia memiliki sumder daya alam yang sangat melimpah. Hal ini dikarenakan kurangnya inovasi dan kreativitas penduduk Negara Indonesia dalam memanfaatkan sumber daya tersebut.

Seperti Singapura yang merupakan Negara dengan jumlah wirausaha tertinggi di ASEAN, kemudian Malaysia. Hal ini cukup memprihatinkan, mengingat Indonesia memiliki sumder daya alam yang sangat melimpah. Hal ini dikarenakan kurangnya inovasi dan kreativitas penduduk Negara Indonesia dalam memanfaatkan sumber daya tersebut.

Jika hal-hal tersebut terus dibiarkan, kewirausahaan di Indonesia tidak akan berkembang dan tidak dapat meningkatkan perekonomian Indonesia. Oleh karena itu, dibutuhkan perhatian pemerintah serta kesadaran masyarakat dalam mengembangkan bidang kewirausahaan. Dengan berkembangnya kewirausahaan, dapat mengembangkan perekonomian negara. Contohnya, bertambahnya devisa negara karena banyaknya investor yang menanamkan modalnya di Indonesia. Penduduk dapat membantu mewujudkan peningkatan perekonomian dengan berwirausaha dan memanfaatkan sumber daya alam yang tersedia di Indonesia. Dengan demikian omset dari usaha tersebut 
dapat menentukan pajak yang membantu menambah pendapatan negara. Perkembangan kewirausahaan juga dapat mengurangi jumlah pengangguran, jika demikian negara Indonesia dapat terus berkembang bahkan menjadi Negara maju.

\subsection{Tujuan Penelitian}

Penelitian ini bertujuan untuk memberikan menjawab seputar pertanyaanpertanyaan dalam bidang kewirausahaan di Indonesia, yaitu:

1. Usulan program yang dapat diberikan kepada Kementerian Koeprasi dan UKM dalam mengejar target 2\% pengusaha di Indonesia, khususnya yang melibatkan peran akademisi, mahasiswa dan pelaku usaha?

2. Bagaimana teknis pelaksanaan dari usulan program tersebut jika jadi dilakukan di Indonesia?

3. Dalam kurun waktu berapa tahun target presentase $2 \%$ wirausaha secara nasional dapat dicapai dengan adanya program tersebut?

\section{TINJAUAN PUSTAKA}

Pengertian wirausaha berbeda-beda menurut para ahli, namun dapat diambil benang merah dari tiap-tiap pendapat yang dikemukakan. Menurut Bygrave (2004) wirausaha adalah pencipta kekayaan melalui inovasi, pusat pertumbuhan pekerjaan dan ekonomi, dan pembagian kekayaan yang bergantung pada kerja keras dan pengambilan risiko, sehingga wirausaha diharapkan dapat memanfaatkan berbagai kesempatan yang ada untuk memulai menjadi wirausaha.

Pendapat lain mengatakan bahwa wirausaha adalah orang-orang yang mempunyai kemampuan melihat dan mengumpulkan sumber-sumber daya yang dibutuhkan guna mengambil keuntungan dari padanya serta mengambil tindakan yang tepat, guna memastikan kesuksesan (Meredith et.al, 2000). Kewirausahaan adalah semangat, perilaku dan kemampuan untuk memberikan tanggapan yang positif terhadap peluang memperoleh keuntungan untuk diri sendiri dan atau pelayanan yang lebih baik pada pelanggan/masyarakat, dengan selalu berusaha mencari dan melayani langganan produk yang lebih bermanfaat dan menerapkan cara kerja yang lebih efesien, melalui keberanian mengambil resiko, kreativitas dan inovasi serta kemampuan manajemen (Salim Siagian, 1998).

Terdapat beberapa teori yang tentang kewirausahaan dalam hubungannya dengan pembangunan suatu negara. Berikut ini adalah beberapa diantaranya:

\section{a. Teori Schumpeter (1912)}

Schumpeter berkeyakinan bahwa pembangunan ekonomi terutama diciptakan oleh inisiatif dari golongan pengusaha yang inovatif dan golongan entrepreneur, yaitu golongan masyarakat yang mengorganisasi dan menggabungkan faktor-faktor produksi lainnya untuk memproduksi barang-barang yang dibutuhkan masyarakat. Schumpeter memiliki pandangan bahwa proses pembangunan yang stagnan yakni tidak terdapat perkembangan penduduk, tidak ada penanaman modal baru dan pengangguran baru, wirausaha akan mulai memainkan perannya. Kelompok wirausaha ini melakukan penanaman modal baru dan menggunakan faktor-faktor lainnya untuk melaksanakan dan menciptakan berbagai pembaharuan. Pada akhirnya hal tersebut akan mengakibatkan terjadinya peningkatan ekonomi yang tinggi.

\section{b. Teori McClelland: N-Ach (1961) \\ Teori yang dikembangkan oleh Mc} Clelland ini mengungkapkan bahwa salah satu faktor yang menjadikan maju-tidaknya suatu bangsa ialah banyak-sedikitnya penduduk yang terjangkit virus $\mathrm{N}$-Ach. NAch atau Need for Achieving merujuk pada hasrat seseorang untuk melakukan pencapaian. Jadi semakin banyak anggota masyarakat yang punya semangat N-Ach, akan semakin maju suatu bangsa. 
Seseorang yang terjangkit virus $\mathrm{N}$ Ach ini akan memperlihatkan perilaku yang selalu ingin meraih prestasi, bekerja keras, penuh tanggung jawab, dan berani mengambil resiko. Bukankah itu juga merupakan ciri-ciri seorang wirausaha? Dengan demikian dapat disimpulkan bahwa maju atau tidaknya suatu bangsa, salah satunya ditentukan oleh sedikit banyaknya jumlah penduduk yang bermental wirausaha.

\section{c. Teori Rachbini (2001)}

Menurut Rachbini, masalah kewirausahaan merupakan persoalan paling penting di dalam perekonomian suatu bangsa yang sedang membangun. Kemajuan atan kemunduran ekonomi suatu bangsa sangat ditentukan oleh keberadaan dan peranan kelompok wirausahawan ini. Jika suatu bangsa tidak memiliki modal manusia seperti ini, jangan harap ada kemajuan pada bangsa tersebut. Sebaliknya, kemajuan yang terjadi pada suatu bangsa dapat dilihat dari keberadaan dan peranan kelompok wirausahawannya.

d. Teori Lima Tahap Pembangunan dari W.W Rostow (1971)

Peranan kewirausahaan memiliki peran penting bagi pembangunan ekonomi suatu negara karena dengan adanya wirausaha maka akan ada inovasi dan gagasan baru yang dihasilkan. Menjadi jelas kiranya meskipun suatu negara kaya sumber daya alam tetapi ada dalam golongan negara berpendapatan rendah apabila tidak memiliki wirausaha yang mampu mengolah SDA tersebut untuk kesejahteraan negaranya. Menurut Rostow (Arsyad, 1992: 39-41), proses pembangunan ekonomi bisa dibedakan kedalam 5 tahap:

1. Masyarakat tradisional

2. Tahap prasyarat tinggal landas

3. Tahap tinggal landas

4. Tahap menuju kedewasaan

5. Masa konsumsi energi
Wirausaha memberikan beberapa manfaat seperti meningkatkan produktivitas, meningkatkan pertumbuhan ekonomi, menciptakan teknologi baru, menciptakan produk dan jasa baru, mendorong inovasi, menciptakan pekerjaan dan membantu organisasi bisnis besar. Meningkatkan Produktivitas. Dengan menggunakan metode baru, wirausaha dapat meningkatkan produksi. Meningkatkan Pertumbuhan Ekonomi dan Menciptakan Pekerjaan, wirausaha serta usaha kecil memberikan lapangan kerja yang cukup besar sehingga dapat memberi kontribusi terhadap pertumbuhan ekonomi. Menciptakan teknologi baru dan menciptakan produk dan jasa baru, banyak wirausaha yang memanfaatkan peluang dengan menciptakan produk atau jasa baru, Kalaupun mereka masih mempertahankan produk lama, produk tersebut merupakan produk yang sudah diperbaiki, wirausaha juga banyak yang mengembangkan teknologi baru untuk produksi barang.

Dari keempat teori tersebut menggambarkan bahwa kewirausahaan adalah sesuatu yang bisa dibentuk, dibina, dan dikembangkan. Schumpeter mengawalinya dengan teori kemajuan pembangunan yang dimulai dari masyarakat yang cerdas mengelola faktorfaktor produksi agar bermanfaat bagi banyak orang. McClelland lebih bersifat aplikatif dengan menankam hasrat yang berapi-api dalam diri masyarakat untuk menjadi produktif dan berprestasi, yang lebih mengarah pada membentuk usaha baru. Rachbinni menekankan pada jiwa kewirausahaan yang harus ditanamkan kepada masyarakat untuk membawa perubahan kemajuan bangsa. Rostow menguraikan teori-teori pembangunan manusia dalam hal berwirausaha dalam lima tahapan di masyarakat. Dengan demikian tingkat persentase kewirausahaan dalam masyarakat seyogyanya dapat diusahakan, dikondisikan dan dibina sedemikian mungkin agar tercipta 
penambahan yang signifikan secara nasional.

\section{METODE PENELITIAN}

Penelitian ini menggunakan pendekatan induktif, yang berusaha mengemukakan sebuah gagasan mencipatkan sebuah program yang dapat digeneralisasi. Analisa yang dilakukan bersifat kombinasi kualitatif dan kuantitatif. Pada tahap awal, dilakukan analisa konten terhadap semua data sekunder yang diolah secara kualitatif sehingga menghasilkan suatu pemaparan ide skema program yang dapat diterapkan dengan melibatkan Kementerian Koperasi dan UKM RI, Akademisi dan Mahasiswa, beserta Pelaku Usaha. Penelitian dilanjutkan dengan analisa kuantitatif yang menggunakan rumus matematika dasar yang timbul akibat dari usulan program tersebut. Penelitian tidak melakukan metode survey atau observasi karena, hanya menggunakan data yang sudah ada, diolah sedemikian rupa dengan perhitungan matematika sederhana untuk dapat menjawab pertanyaanpertanyaan penelitian yang dituliskan dalam tujuan penelitian. Perhitungan tersebut dapat dijabarkan sebagai berikut:

1. (Jumlah wirausahawan yang ingin dicapai) - (Jumlah wirausahawan saat ini) $=$ Target penambahan wirausahawan baru nasional.

2. (Jumlah perguruan tinggi saat ini) $\mathrm{x}$ (Target penambahan unit usaha per perguruan tinggi) $\mathrm{x}$ (Jumlah mahasiswa per unit usaha) $=$ Target penambahan wirausahawan baru tiap tahun.

3. (Target penambahan wirausahawan baru) / (Target penambahan wirausahawan baru per tahun) = Jumlah tahun yang dibutuhkan untuk mencapai target nasional .

Penulisan ini melanjutkan dan mengembangkan penelitian sebelumnya yang dilakukan oleh Ohe dan Goi (2014) tentang ekosistem kewirausahaan di universitas-universitas di kawasan ASEAN. Perbedaannya adalah bahwa pada penelitian sebelumnya tersebut menitikberatkan pada pelaksanaan program kolaborasi yang dilakukan di negara-negara ASEAN, sedangkan pada penelitian ini lebih kepada mengembangkan usulan program ini di Indonesia dalam menciptakan sistem yang dapat diterapkan untuk mencapai target wirausahawan Indonesia sebesar $2 \%$.

\section{HASIL DAN PEMBAHASAN}

Setelah mengkaji sumber-sumber pustaka dalam analisa konten, maka didapatkan indikator-indikator bahwa seseorang dapat dikatakan sebagai wirausahawan sesungguhnya apabila memenuhi kriteria-kriteria tertentu. Dalam hal menghitung jumlah wirausahawan, seseorang layak disebut sebagai wirausahawan adalah memenuhi ke-empat unsur berikut:

1. Memiliki kegiatan usaha atau tingkat kepemilikan bisnis yang menerapkan prinsip-prinsip manajemen dengan salah satu tujuannya mencari laba.

2. Sebagian besar masyarakat yang berada pada tahap pra-bisnis, tahap memulai bisnis (start-up business), dan tahap awal bisnis. Definisi ini cenderung ke arah wirausaha yang baru memulai bisnis karena mereka merupakan sasaran dari langkahlangkah kebijakan yang berkenaan dengan kewirausahaan.

3. Adanya konsep "kebaruan" yaitu usaha tersebut mengandung unsur yang diciptakan sendiri, tidak semata-mata menjiplak konsep usaha yang sudah ada.

4. Adanya ketahanan hidup atau keberlangsungan suatu usaha setidaknya selama beberapa tahun.

Sebagaimana disebutkan diawal bahwa $1,65 \%$ dari jumlah penduduk di 
Indonesia atau sekitar 4.23 juta orang dapat dikategorikan sebagai wirausahawan, sedangkan menurut berbagai sumber bahwa indikator negara maju salah satunya ialah bahwa persentase jumlah wirausahawan adalah 2\% dari jumlah penduduk yakni sekitar 5.16 juta orang. Sehingga untuk mencapai hal ini, diharapkan tumbuh setidaknya 900ribu-an wirausahawan baru. Dengan data nasional bahwa terdapat 57,9 juta unit usaha, namun hanya 4,23 juta yang digolongkan sebagai wirausahawan. Jika diasumsikan satu pengusaha dengan satu unit usaha, maka dari 15 orang yang melakukan wirausaha, hanya 1 yang memenuhi empat kriteria wirausahawan.

Oleh karena itu pemerintah perlu menciptakan iklim untuk mendukung kewirausahaan di Indonesia, bahkan program-program untuk menciptakan wirausahawan-wirausahawan baru. Sebuah contoh sederhana adalah dengan memberikan kebebasan berwirausaha yang lebih leluasa dan memudahkan sistem perijinannya. Data menunjukkan bahwa dari tingkat Ease of Doing Business, dari tahun 2016 ke tahun 2017, Indonesia naik 15 peringkat, dari peringkat 106 ke 91 . Kabar menggembirakan ini diharapkan akan terus menaik, salah satunya dengan mencontoh negara-negara maju lainnya seperti New Zealand yang berada di peringkat pertama dunia.

Dari total seluruh unit usaha yang sekitar 59,7 juta, sektor Usaha Mikro Kecil dan Menengah (UMKM) memiliki bagian terbesar yakni $97 \%$ atau sekitar 57,9 unit usaha. Sektor Koperasi hanya memiliki bagian 0,4\% atau 209 ribu unit usaha. Produk Domestik Bruto di Indonesia adalah 11.913 Trilyun rupiah, sektor UMKM menyumbang $60 \%$ kontribusi yaitu sekitar 6.749 Trilyun. Jumlah tersebut dapat dikatakan cukup, mengingat sektor UMKM di negara-negara maju sekitar 50\%-60\%. Untuk sektor koperasi, amat disayangkan bahwa hanya memiliki kontribusi sebesar 1,7\% atau sekitar 190 Trilyun. Sedangkan negara-negara maju memiliki kontribusi sektor koperasi terhadap PDB diatas 6\%. Sehingga jika, persentase $6 \%$ tersebut adalah target yang perlu dicapai oleh sektor koperasi, maka diharapkan kontribusi sektor tersebut naik menjadi 672 Trilyun, dengan penambahan pendapatan sebesar 481 Trilyun per tahun.

Oleh karena hal-hal di atas maka pemerintah amat perlu untuk mendorong suatu iklim ekonomi yang mengembangkan dua sektor utama tersebut, yakni Koperasi dan Usaha Kecil Menengah (UKM). Jika pada sektor UKM, strategi yang dapat dilakukan adalah dengan menaikkan jumlah wirausaha baru. Untuk sektor Koperasi lebih diharapkan untuk membesarkan nilai bisnis koperasi-koperasi yang sudah ada.

Program

pengembangan kewirausahaan yang dihasilkan dalam penelitian ini adalah: Kolaborasi antara Akademisi (Dosen/Pengajar) - Mahasiswa - Pelaku UKM difasilitasi oleh Kementerian Koperasi dan UKM RI. Jepang sebagai negara maju memiliki program jenis ini yang diperuntukkan bagi negara-negara di ASEAN dengan nama: Cosulting-based Learning for ASEAN SMEs (COBLAS). Program tersebut memfasilitasi para pelaku UKM di negaranegara ASEAN agar mendapat ilmu dan bimbingan dari para akademisi lewat konsultasi serta mendapat pendampingan dari mahasiswa-mahasiswi dengan jurusan yang terkait dengan bidang usaha UKM yang didampinginya agar dapat berkembang dan semakin maju. COBLAS merupakan program yang diberikan secara cuma-cuma oleh Pemerintah Jepang kepada negara-negara ASEAN yang telah berlangsung sejak tahun 2003 hingga saat ini. Program ini cukup berhasil di Malaysia dengan menyasar mahasiswa program Master of Business Administration (MBA). Lanjutan dari program ini adalah International Business Partnership Program, yaitu mempertemukan antara para pelaku UKM di negara-negara 
ASEAN dengan melakukan metode business matching. Metode ini adalah mengusahakan agar terjadi kerjasama antara dua UKM negara ASEAN yang memiliki bidang yang berkaitan, dengan ekspektasi lahirnya Born ASEAN SMES (Small Medium Enterprises), yaitu UKM yang lahir dari kolaborasi negara-negara ASEAN.

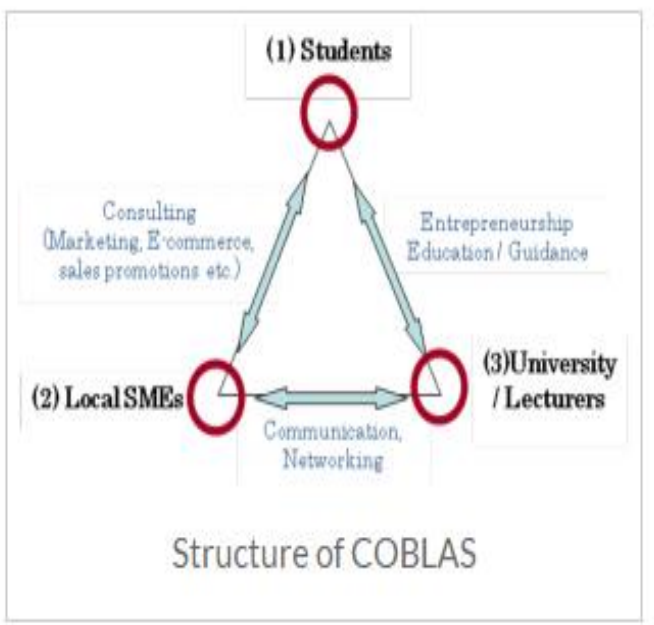

Gambar 1. Penerapan Metode Consulting-Based Learning for ASEAN SMEs (COBLAS)

Sumber diakses pada tanggal 12 Januari 2018 dari: http://asnep.asia/coblas/

Mengambil rujukan pada Gambar 1 diatas, yang telah diterapkan di negaranegara ASEAN dengan bantuan dana ASEAN Integration Fund (JAIF), maka Indonesia dapat pula menerapkan semacam program tersebut, dengan beberapa pengembangan yang diperlukan, dalam meningkatkan presentase kewirausahaan di Indonesia yang semula $1,65 \%$ menjadi $2 \%$. Konsep yang dihasilkan oleh penelitian ini adalah diusulkan agar didirikan Entrepreneurship Center (Pusat Kewirausahaan) di tiap Dinas Koperasi dan UKM yang terdapat di kotamadya/ kabupaten. Pusat Kewirausahaan ini haruslah bekerjasama dengan universitasuniversitas, dan pelaku usaha kecil dan menengah. Program dapat dinamakan, misalnya: Program Kewirausahaan antara Perguruan Tinggi dan Pelaku Usaha
(Program KPTPU), yang dapat

digambarkan sebagai berikut:

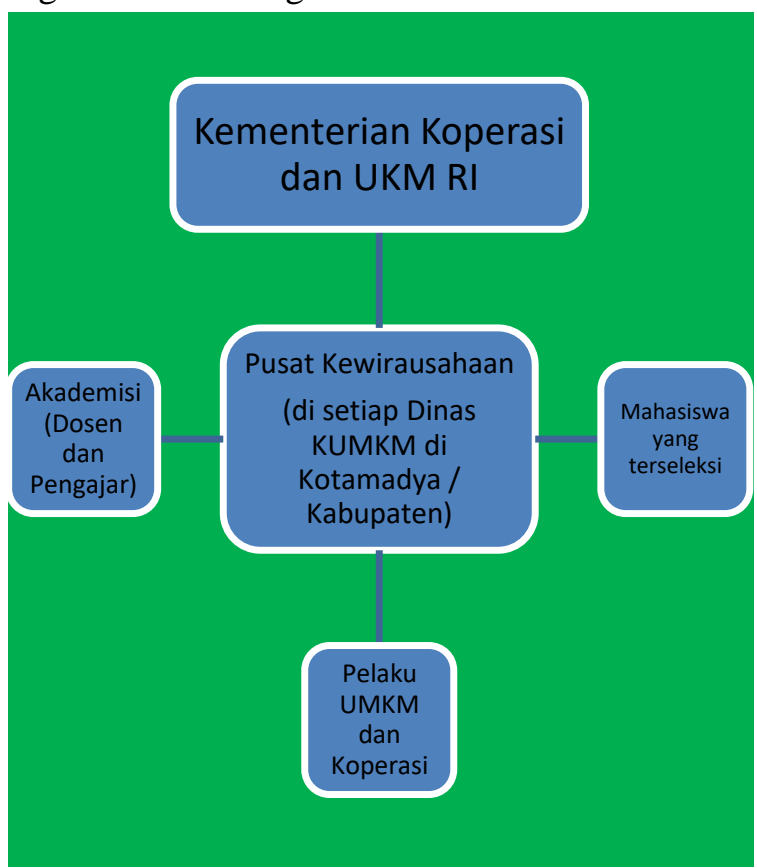

Gambar 2. Program Kewirausahaan antara Perguruan Tinggi dan Pelaku Usaha (KPTPU)

Langkah-langkah yang selanjutnya dapat dilakukan adalah antara lain:

1. Kementerian Koperasi dan Usaha Kecil Menengah (KUKM) melakukan pendataan ulang dengan sistem database tunggal di seluruh Indonesia, agar dapat teranalisa dengan baik jumlah UKM per kategori di tingkat kabupaten/kota.

2. Jumlah 539 kabupaten/kota yang memiliki perguruan tinggi sebanyak 3.225 perguruan tinggi. Program ini dapat menerapkan penetapan target satu perguruan tinggi menghasilkan 10 wirausaha baru setiap tahun.

3. Pendaftaran dilanjutkan dengan seleksi dosen dan mahasiswa yang ingin tergabung dengan program ini. Pelaksanaan terdiri dari tiga tahap. Tahap 1, yaitu selama 3 bulan membantu kinerja satu unit UKM yang sudah berjalan. Tahap 2, adalah program 6 bulan dimana para peserta membentuk unit-unit usaha (UKM) mereka sendiri. Tahap 3 merupakan 
evaluasi, yaitu selama 3 bulan dilakukan penentuan UKM-UKM yang layak dilanjutkan atau tidak.

4. Pelaksanaan secara teknis adalah sebagai berikut. Tahap 1, dibentuklah kelompok-kelompok kerja kecil yang terdiri dari: 1 Pelaku Usaha, 5 orang Mahasiswa, dan 1 Dosen. Kelompok ini bekerjasama dalam rangka membantu kinerja UKM yang menjadi proyek per kelompok kerja. Pada tahap awal ini diterapkan penggabungan teori dan praktek. Dosen sebagai pemimpin proyek, para mahasiswa sebagai pendamping pelaku usaha, membantu mengembangkan unit UKM di kelompoknya masing-masing. Pada Tahap 2, program melatih para mahasiswa benar-benar menerapkan pembentukan unit UKM sesuai ide yang merupakan hasil dari teori dan praktek. Disini pelaku usaha tidak diikutkan lagi. Jadi tiap kelompok kerja, mulai membuat model bisnis yang baru dan menerapkannya dalam dunia nyata. Pada Tahap 3, Kementerian Koperasi dan UKM RI lewat dinas-dinas yang berada di tingkat kabupaten/kota menyeleksi semua usaha-usaha yang dibentuk oleh kelompok-kelompok kerja tersebut. Bagi UKM-UKM baru yang lolos seleksi, selain dimasukkan kedalam database kementerian, juga perlu diberikan fasilitas-fasilitas tambahan sebagai prioritas.

5. Program berlangsung secara berkesinambungan setiap satu tahun sekali selama 5 tahun atau lebih.

Target penambahan wirausahawan baru dapat dijelaskan sebagau berikut: penjelasan sebagai berikut:

1. $(2 \% \times 258$ juta penduduk $)-(1.65 \% \times$ 258 juta penduduk) $=900.000$ wirausahawan baru.

2. 3.225 perguruan tinggi $\mathrm{x} 10$ target UKM baru $\mathrm{x} 5$ mahasiswa calon wirausahawan

$=$

161.250

wirausawahan baru per tahun.

3. 900.000 target wirausahawan baru / 161.250 wirausahawan baru per tahun $=6$ tahun yang dibutuhkan untuk pencapaian target nasional.

Dengan usulan program yang dihasilkan, maka pertanyaan-pertanyaan penelitian telah terjawab. Skema ini menjadi suatu stimulus yang signisikan bagi penambahan jumlah wirausahawan baru karena setiap unit UKM baru yang terbentuk terdapat 5 wirausahawan baru di dalamnya, yang adalah para mahasiswa di kelompok-keleompok kerja program KPTPU tersebut.

Jika dilakukan selama 6 tahun berturut-turut maka diharapkan target $2 \%$ jumlah wirausahawan dari penduduk Indonesia tercapai. Semua perhitungan ini mengabaikan adanya pertumbuhan secara alami (organic growth) yang terjadi setiap tahunnya meskipun tanpa diberikan suatu program atau stimulus tertentu. Sehingga bukan tidak mungkin target tersebut dapat dicapai dalam waktu kurang dari 6 tahun, dengan catatan bahwa setiap perguruan tinggi menghasilkan 10 UKM baru dengan 5 orang mahasiswa di masing-masing usaha baru tersebut setiap tahun.

\section{KESIMPULAN DAN SARAN}

\subsection{Kesimpulan}

Dalam meningkatkan kewirausahaan di Indonesia diperlukan program yang mengkolaborasikan akademisi - pelaku UKM - mahasiswa difasilitasi oleh Kementerian Koperasi dan UKM RI. Dengan sistem yang terstruktur dan sistematis dilakukan di seluruh daerah di Indonesia, maka diharapkan akan timbul wirausahawan-wirausahawan baru yang berkualitas. Persentase $1,65 \%$ jumlah wirausahawan dari total populasi dapat kita tingkatkan menjadi $2 \%$ dalam kurun waktu 5-6 tahun kedepan. 


\subsection{Saran}

Sebagai rekomendasi, dapat pula dilakukan program pendamping yaitu kompetisi bagi UKM-UKM baru tersebut, sebagai penghargaan bagi para mahasiswa yang memiliki talenta dan motivasi kuat untuk berwirausaha.

Penelitian ini dapat dilanjutkan dengan pengkajian aspek hukum dan lingkungan untuk memastikan apakah program ini dapat benar-benar diterapkan sebagai program nasional di Indonesia.

\section{DAFTAR PUSTAKA}

Adisasmita, Rahardjo. 2011. Manajemen Pemerintah Daerah. Yogyakarta: Penerbit Graha Ilmu

Arsyad, Lincolin. 1992. Pembangunan Ekonomi, Edisi 2. Yogyakarta: STIE YKPN.

Bygrave, William D. 1994. The Portable MBA in Entrepreneurship. Singapore: John Wiley and Sons, Inc.

Geoffrey G. Meredith, et al. 2000. Teori dan Praktek Kewirausahaan. Pustaka Binaman Pressindo, Jakarta.

Mansor.M, Othman.N., 2011 International Conference on Social Science and Humanity IPEDR vol.5, IACSIT Press, Singapore

McLelland, D. 1961. The Achieving Society. London. Free Press.

Ohe, T \& Goi, H.C (2010), COBLAS Program for Entrepreneurship Education in ASEAN Universities. Asia Science and Education for Economic Development.

Rachbini, D.J. 2001. Pengembangan Ekonomi \& Sumber Daya Manusia, Grasindo Jakarta.

Schumpeter, J.A. 1912. The Theory of Economic Development. Cambridge MA. Harvard University Press.

Siagian, Salim, 1999, Peranan Kewirausahaan Pengembangan Koperasi, Usahawan No. 07 THXXVIII Juli. 